\title{
Ultrasounds pretreatment of olive pomace to improve xylanase and cellulase production by solid-state fermentation
}

\author{
Paulina Leite ${ }^{\mathrm{a}}$, José Manuel Salgado ${ }^{\mathrm{a}, *}$, Armando Venâncio ${ }^{\mathrm{a}}$, José Manuel Domínguez ${ }^{\mathrm{b}}$, Isabel Belo ${ }^{\mathrm{a}}$ \\ ${ }^{a}$ CEB - Centre of Biological Engineering, University of Minho, Campus de Gualtar, 4710-057 Braga, Portugal \\ ${ }^{\mathrm{b}}$ Department of Chemical Engineering, Sciences Faculty, University of Vigo (Campus Ourense), As Lagoas s/n, 32004 Ourense, Spain
}

\section{H I G H L I G H T S}

- Ultrasounds as potential pretreatment for lignocellulosic residues.

- Improve cellulase and xylanase production by solid-state fermentation.

- Evaluation of wastes from new olive oil extraction system.

- Physicochemical comparison of olive mill wastes.

- Selection of best producers of cellulases and xylanases.

\section{A R T I C L E I N F O}

\section{Article history:}

Received 23 March 2016

Received in revised form 9 May 2016

Accepted 10 May 2016

Available online 12 May 2016

\section{Keywords:}

Ultrasounds pre-treatment

Solid-state fermentation

Xylanases

Cellulases

Olive pomace

\begin{abstract}
A B S T R A C T
Olive mills generate a large amount of waste that can be revaluated. This work aim to improve the production lignocellulolytic enzymes by solid-state fermentation using ultrasounds pretreated olive mill wastes. The composition of olive mill wastes (crude and exhausted olive pomace) was compared and several physicochemical characteristics were significantly different. The use of both wastes in SSF was evaluated and a screening of fungi for xylanase and cellulase production was carried out. After screening, the use of exhausted olive pomace and Aspergillus niger led to the highest enzyme activities, so that they were used in the study of ultrasounds pre-treatment. The results showed that the sonication led to a 3 -fold increase of xylanase activity and a decrease of cellulase activity. Moreover, the liquid fraction obtained from ultrasounds treatment was used to adjust the moisture of solid and a positive effect on xylanase (3.6-fold increase) and cellulase (1.2-fold increase) production was obtained.
\end{abstract}

(c) 2016 Elsevier Ltd. All rights reserved.

\section{Introduction}

Over the past decade, the olive mills have changed their traditional extraction method from the three phase system to the two-phase system. This change improves the olive oil quality and reduces wastewaters disposal costs because the two phase system barely generates wastewaters (Khdair et al., 2015). However, it generates a wet olive pomace or crude olive pomace (COP) whose handling is more difficult and cause more disposal problems than the pomace obtained by the three phase system (Cayuela et al., 2010). The COP needs new alternatives to reduce its environmental and economic impact. In the 2014/15 season, global olive oil production was around $2,287,000 \mathrm{t}$, according to the International Olive Council. Per ton of processed olives, $800-950 \mathrm{~kg}$ of COP are produced (Azbar et al., 2004), as a result 1,829,600 $t$ of COP are

\footnotetext{
* Corresponding author.

E-mail address: jmsalgado@uvigo.es (J.M. Salgado).
}

generated each year. Currently, olive oil industries recover residual olive oil from COP. This waste has around 3.5\% residual oil in wet basis. In spite of the doughy consistency hinder the drying of COP, the extraction of residual oil is still applied (Rincón et al., 2012). After olive oil extraction and a drying step, the exhausted olive pomace (EOP) can be used in combustion processes. However, combustion of EOP causes environmental problems due to the emission of toxic compounds in gas form (Niaounakis and Halvadakis, 2006) and it requires high energy consumption to reduce the moisture content. Thus, it is necessary to search new alternatives that could increase the value of these wastes and reduce their environmental impact. The investment in the revalorization of this waste is a current opportunity, and it may also contribute to the protection of the environment.

The use of EOP as solid substrate in solid-state fermentation (SSF) is an attractive solution, since due to its lignocellulosic nature can be an inductor of lignocellulolytic enzymes. However, its direct use in biological processes is not possible due to its high 
organic load, presence of antimicrobial compounds such phenols and lipids, low $\mathrm{pH}$ value and low nutrients concentration (Morillo et al., 2009). These barriers can be overcome in biotechnology processes by mixing with other wastes (Salgado et al., 2014a, 2015; Oliveira et al., 2016) or by pre-treatments (Gianico et al., 2013).

Pre-treatments enhance the biodigestibility and porosity of the residues and increase the accessibility of microorganisms to the materials improving the production of enzymes by SSF. To select the most appropriate pre-treatment, several criteria must be taken into account such as to minimize loss of hemicelluloses and cellulose, do not require the addition of toxic chemicals, minimize the use of energy, low capital equipment and chemicals demand, as well as the possibility of an easier scale-up (Holtzapple and Humphrey, 1984). Sonication largely meets these criteria, it is a physical treatment that can increase size of pores and accessible surface area, decrease degrees of polymerization of cellulose and crystallinity and improve the biodegradability or enzymatic hydrolysis of the residues (Taherzadeh and Karimi, 2008). Ultrasound pre-treatment (US) causes cavitation bubbles formation in the liquid phase, the bubbles grow and then violently collapse when they reach a critical size. US is influenced by four main factors: specific energy, ultrasonic frequency, application time, and the characteristics of the substrate (Rincón et al., 2014). The US is widely used as pre-treatment for anaerobic digestion processes with promising results (Rincón et al., 2014). However, the use of US pretreated solid as substrate in SSF was barely studied.

The SSF also appears as an attractive alternative to submerged fermentation $(\mathrm{SmF})$. In SSF the microbial growth and product formation occurs at or near the surface of the solid substrate particle having low moisture contents. There are several potential advantages for bioprocessing and production of various value-added products compared to submerged fermentation, because products have higher yield, lower energy requirements and produces less wastewater with less risk of bacterial contamination (Pandey et al., 2007).

In recent years, it has been an increasing interest in the production of enzymes using low-cost processes as SSF. In this sense the agro-industrial substrates are considered suitable for enzyme production by SSF. Cellulases and xylanases are lignocellulolytic enzymes with applications in several industrial sectors as biofuels industries. Given the advantages of enzymatic route in bioethanol production from lignocellulosic residues, there is an increasing demand in the production of enzymatic cocktails containing cellulases and xylanases that allows an efficient saccharification of cellulose in lignocellulosic residues (Zimbardi et al., 2013). Several fungi are able to produce this enzyme cocktail; Trichoderma reesei and Aspergillus niger are the main industrial sources of cellulases and xylanases due to their ability to secrete high quantities of hydrolytic enzymes. Recently, the filamentous fungi Aspergillus uvarum and Aspergillus ibericus have been identified as producers of cellulases and xylanases (Salgado et al., 2014b).

Considering that the use of olive pomace as alone solid substrate in SSF is difficult and the growing interest in enzyme cocktails containing cellulase and xylanase, the aim of this paper was to examine the effect of US on the production of enzymatic cocktails containing these enzymes. In addition, a screening of filamentous fungi was performed to select the most suitable fungi to produce this enzymatic cocktail, and the composition of COP and EOP were compared.

\section{Materials and methods}

\subsection{Raw material}

The crude olive pomace (COP) and exhausted olive pomace (EOP) were collected from olive oil industry of northern Portugal in season 2013/2014. COP is a semi-solid waste of the two-phase system that was recovered after olive oil extraction. EOP is obtained after recovery of residual olive oil from COP and dried to use in combustion processes. The COP and EOP were stored at $-20^{\circ} \mathrm{C}$ and at room temperature and dry conditions, respectively.

\subsection{Characterization of olive pomace}

Both olive pomaces were analysed for the physical-chemical characterization. It was determined the moisture, total solids and ashes. Total nitrogen and organic carbon were determined by a Thermo Finningan Flash Element Analyzer 1112 series, San Jose, CA (USA) and metals, such as $\mathrm{Ca}, \mathrm{K}, \mathrm{Mg}, \mathrm{Na}, \mathrm{Zn}, \mathrm{Cu}, \mathrm{Fe}, \mathrm{Mn}, \mathrm{Cr}, \mathrm{Ni}$ and $\mathrm{Pb}$ were analysed in ashes using Flame Atomic Absorption and Atomic Emission Spectrometry (FFAS/FAES) FAAS/FAES. The organic constituents of olive pomace such as cellulose, hemicellulose and Klason lignin were characterized by quantitative acid hydrolysis (QAH) in a two-stage acid treatment. The first stage with $72 \%$ wt $\mathrm{H}_{2} \mathrm{SO}_{4}$ at $30{ }^{\circ} \mathrm{C}$ for $1 \mathrm{~h}$ and the second stage after dilution to $4 \%$ wt $\mathrm{H}_{2} \mathrm{SO}_{4}$ at $121^{\circ} \mathrm{C}$ for $1 \mathrm{~h}$. The solution was filtered through a Gooch crucible to retain lignin and these were introduced in the hot air oven at $105^{\circ} \mathrm{C}$. The filtrate was analysed by High Performance Liquid Chromatography system using a Jasco830-IR intelligent refractive-index detector and a Varian MetaCarb $87 \mathrm{H}$ column. The column was eluted with $0.005 \mathrm{M}$ $\mathrm{H}_{2} \mathrm{SO}_{4}$ and the flux was $0.7 \mathrm{~mL} / \mathrm{min}$ at $60^{\circ} \mathrm{C}$. The total fat content was extracted with diethyl ether, in a Soxtec System HT2 1045 Extraction Unit. In order to analyse the free reducing sugar, proteins and total phenols in olive pomaces, an extraction with water ( $\mathrm{S}: \mathrm{L}$ ratio, 1:5 w/v) was performed. Free reducing sugars, total phenols and free protein were measured according to Salgado et al. (2014b). These determinations were performed in triplicate.

Table 1

Screening of filamentous fungi to verify ability to produce extracellular cellulases and xylanases.

\begin{tabular}{|c|c|c|c|c|c|}
\hline Fungi & Code & Cellulases E:I & SD & Xylanases E:I & SD \\
\hline Aspergillus niger & 01UAs181 & $1.120^{\mathrm{cd}}$ & 0.000 & $1.064^{\mathrm{abc}}$ & 0.030 \\
\hline Aspergillus niger & 01UAs183 & $1.064^{\mathrm{b}}$ & 0.008 & $1.034^{\mathrm{ab}}$ & 0.001 \\
\hline Aspergillus niger & CECT 2088 & $1.058^{\mathrm{b}}$ & 0.001 & $1.054^{\mathrm{abc}}$ & 0.000 \\
\hline Aspergillus niger & CECT 2700 & $1.067^{\mathrm{bc}}$ & 0.001 & $1.087^{\mathrm{bc}}$ & 0.028 \\
\hline Aspergillus niger & CECT 2915 & $1.140^{\mathrm{d}}$ & 0.000 & $1.258^{\mathrm{d}}$ & 0.029 \\
\hline Aspergillus ibericus & MUM 03.49 & $1.123^{\mathrm{d}}$ & 0.003 & $1.245^{\mathrm{d}}$ & 0.032 \\
\hline Aspergillus ibericus & MUM 2004 & $1.111^{\mathrm{bcd}}$ & 0.000 & $1.061^{\mathrm{abc}}$ & 0.000 \\
\hline Aspergillus ibericus & 03UAs268 & $1.086^{\mathrm{bcd}}$ & 0.022 & $1.033^{\mathrm{ab}}$ & 0.077 \\
\hline Aspergillus uvarum & MUM 08.01 & $1.123^{\mathrm{d}}$ & 0.071 & $1.200^{\mathrm{d}}$ & 0.032 \\
\hline Aspergillus carbonarius & 01UAs 130 & $1.123^{\mathrm{d}}$ & 0.030 & $1.112^{\mathrm{c}}$ & 0.047 \\
\hline Trametes versicolor & MUM 04.100 & $0.985^{\mathrm{a}}$ & 0.003 & $1.000^{\mathrm{a}}$ & 0.020 \\
\hline
\end{tabular}

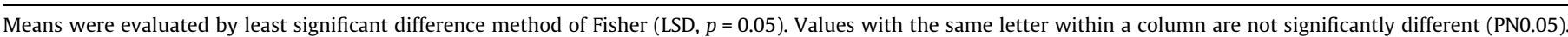




\subsection{Microorganims}

Different species of fungi (mainly Aspergillus spp.) were used in this study and are listed in Table 1 . They were obtained from MUM (Micoteca of University of Minho, Braga, Portugal) and from CECT (Spanish collection of type cultures, Valencia, Spain), where they were preserved in glycerol stocks stored at $-80^{\circ} \mathrm{C}$. They were revived on malt extract agar (MEA) plates $(20 \mathrm{~g} / \mathrm{L}$ malt extract, $1 \mathrm{~g} / \mathrm{L}$ peptone, $20 \mathrm{~g} / \mathrm{L}$ glucose and $20 \mathrm{~g} / \mathrm{L}$ agar). To obtain inocula for SSF, the selected fungi were subcultured on MEA slants, and incubated at $25^{\circ} \mathrm{C}$ for 6 days. During the experimental period, strains were preserved at $4{ }^{\circ} \mathrm{C}$ and cultured monthly on fresh MEA slants.

\subsection{Screening by Congo red test}

The screening of fungi was performed by Congo red test. The assays for cellulases and xylanases producers were carried out on agar plates using carboxymethylcellulose (CMC) and xylan as carbon source, respectively, and Mandel Weber salts medium (composition in $\mathrm{g} / \mathrm{L}$ : urea - 0.3, $\left(\mathrm{NH}_{4}\right)_{2} \mathrm{SO}_{4}-1.4, \mathrm{KH}_{2} \mathrm{PO}_{4}-0.4$, $\mathrm{MgSO}_{4} \cdot 7 \mathrm{H}_{2} \mathrm{O}-0.3$, Peptone -0.75 , Yeast extract $-0.25, \mathrm{FeSO}_{4} \cdot 7 \mathrm{H}_{2} \mathrm{O}$ - 0.005, $\mathrm{MnSO}_{4} \cdot 7 \mathrm{H}_{2} \mathrm{O}-0.001, \mathrm{ZnSO}_{4} \cdot 7 \mathrm{H}_{2} \mathrm{O}-0.001, \mathrm{CoCl}_{2}-0.001$ ). The fungal cultures were inoculated at the centre of plate containing sterile medium and incubated at $25{ }^{\circ} \mathrm{C}$ during 5 days. At the end of 5 days the growth of the microorganism was measured by the diameter of the colony. Each culture plate was stained with $10 \mathrm{~mL}$ aliquot of Congo red dye $(2.5 \mathrm{~g} / \mathrm{L})$. After $15 \mathrm{~min}$, the solution was discarded and the cultures were washed with $10 \mathrm{~mL}$ of $\mathrm{NaCl}$ (1 M). Cellulases and xylanases production was detected by appearance of clear zone of medium around growth colony, pale halo, orange edges around the fungal colony indicative of areas of hydrolysis. This halo was measured for subsequent calculation of the enzymatic index (EI) by the ratio between the diameter of hydrolysis zone and the diameter of the colony. Two replicates per strain were performed for this screening step.

\subsection{Pretreatments of exhausted olive pomace}

\subsubsection{Ultrasounds pretreatment}

The ultrasounds pretreatment (US XE "US:ultrasound pretreatment") of EOP was carried out with a high intensity ultrasonic processor Cole-Parmer 750 model (Illinois, USA) operating at $750 \mathrm{~W}$ and $20 \mathrm{kHz}$. To optimize the operational conditions of sonication a full factorial design $3^{2}$ was planned. The dependent variables studied were cellulase and xylanase activities and the independent variables were the time of sonication and the ratio liquid/solid (w:w), the independent variables considered and their variations ranged from 5 to $15 \mathrm{~min}$ for time of sonication and from 3 to 11 for L:S ratio.

The solid waste ( $30 \mathrm{~g}$ solid dry) was added to vessel and mixed with distilled water. The vessel was placed in a protective box and the tip (diameter $1 / 2^{\prime \prime}$ ) allocated into the vessel. After pretreatment, the solid was recovered by vacuum filtration and dried at $50{ }^{\circ} \mathrm{C}$ for $24 \mathrm{~h}$ in a hot air oven. The treated waste was used as solid substrate in SSF to produce enzymes.

\subsubsection{Diluted acid hydrolysis}

The diluted acid hydrolysis was carried out with dilute sulfuric acid $(3 \% \mathrm{w} / \mathrm{w})$ in flasks with liquid:solid ratio of 8 during $30 \mathrm{~min}$. The liquid phase with hemicellulosic fraction was separated by vacuum filtration and the solid fraction was neutralized by washing with distilled water to $\mathrm{pH}$ 6. The neutralized solid was dried at $50{ }^{\circ} \mathrm{C}$ for $24 \mathrm{~h}$. The solid was used as substrate in SSF.
2.5.3. Sequential ultrasounds treatment and diluted acid hydrolysis

Initially, the EOP was treated by sonication using the optimal conditions optimized previously followed by diluted acid hydrolysis of pretreated solid using the same conditions described above. The treated wastes were used as solid substrate in SSF to produce enzymes.

\subsection{Solid-state fermentation}

SSF was carried out in $500 \mathrm{~mL}$ Erlenmeyer with $10 \mathrm{~g}$ of dried solid substrate. Moisture level was adjusted to $75 \%$ (wet basis) with nutrients solution ( $5 \mathrm{~g} / \mathrm{L}$ peptone, $5 \mathrm{~g} / \mathrm{L}$ yeast extract, $0.2 \mathrm{~g} / \mathrm{L}$ $\mathrm{KH}_{2} \mathrm{PO}_{4}$ ). Erlenmeyers with solid medium were sterilized at $121^{\circ} \mathrm{C}$ for $15 \mathrm{~min}$. In the evaluation of substitutes for these nutrients, a low-cost solution ( $0.04 \mathrm{~g}$ urea/g solid and $0.5 \mathrm{~mL}$ vinasses/ $\mathrm{g}$ solid) or by liquid fraction from US (volume to adjust moisture to $75 \%$ ) with nutrients $(5 \mathrm{~g} / \mathrm{L}$ peptone, $5 \mathrm{~g} / \mathrm{L}$ yeast extract, $0.2 \mathrm{~g} / \mathrm{L}$ $\mathrm{KH}_{2} \mathrm{PO}_{4}$ ).

For the inoculation, fungal spores selected in Congo red test were grown in MEA medium slants tubes and were suspended in a sterile solution ( $1 \mathrm{~g} / \mathrm{L}$ peptone, $0.1 \mathrm{~g} / \mathrm{L}$ tween 80$)$. The inoculum spore concentration was adjusted to $10^{6}$ spores/mL by Neubauer counting chamber. Each Erlenmeyer was inoculated with $2 \mathrm{~mL}$ of the spore suspension and incubated at $30^{\circ} \mathrm{C}$ for 6 days.

The extraction of enzymes was performed with a solution composed of $1 \% \mathrm{NaCl}$ and $0.5 \%$ Triton-X100 at room temperature in an L:S ratio of 5 and with agitation for $1 \mathrm{~h}$. Following, extracts were centrifuged $(4000 \mathrm{~g}, 15 \mathrm{~min})$, filtered through Whatman $\mathrm{N}^{\circ} 1$ filter paper and stored at $4{ }^{\circ} \mathrm{C}$.

\subsection{Analysis of enzyme activities}

The activity of cellulases (endo-1,4-ß-glucanase) was determined with the enzymatic kit Azo-CM-Cellulose S-ACMCL 094/12 (Megazyme International, Ireland). The procedure for determination of cellulases activity was to add $0.5 \mathrm{~mL}$ of suitably diluted enzyme solution in $0.1 \mathrm{M}$ sodium acetate buffer ( $\mathrm{pH} 4.6$ ) and pre-equilibrated at $40{ }^{\circ} \mathrm{C}$ to $0.5 \mathrm{~mL}$ of pre-equilibrated substrate solution (CM-Cellulose $4 \mathrm{M}$ ). Then, the mixture was stirred and incubated at $40{ }^{\circ} \mathrm{C}$ for $10 \mathrm{~min}$. The solution was centrifuged at $1000 \mathrm{~g}$ for $10 \mathrm{~min}$ and the absorbance of the supernatant solution was measured at $590 \mathrm{~nm}$. The enzyme activity was determined by reference to a standard curve. One unit of enzyme activity was defined as the amount of enzyme required to release $1 \mu \mathrm{mol}$ of glucose reducing sugar equivalents from $\mathrm{CM}$-Cellulose in $1 \mathrm{~min}$ at $40^{\circ} \mathrm{C}$ and $\mathrm{pH}$ 4.6. The values of cellulases activity were expressed in $U$ per gram of dry substrate. The tests were performed in triplicate.

The activity of xylanases (endo-1,4- $\beta$-xylanases) was determined with the enzymatic kit Azo wheat arabinoxylan S-AWAXL 05/14 (Megazyme International, Ireland). The procedure to determine of xylanases activity was the same as for the determination of cellulases activity but the buffer solution was $0.1 \mathrm{M}$ sodium acetate buffer $(\mathrm{pH} 4.5)$ and substrate solution was wheat arabinoxylan. One unit of enzyme activity was defined as the amount of enzyme required to release $1 \mu \mathrm{mol}$ of xylose reducing sugar equivalents from wheat arabinoxylan in $1 \mathrm{~min}$ at $40^{\circ} \mathrm{C}$ and $\mathrm{pH}$ 4.5. The values of xylanases activity were expressed in $U$ per gram of dry substrate. The tests were performed by triplicate.

$\beta$-glucosidase activity was determined using $5 \mathrm{mM}$, 4nitrophenyl $\beta$-D-glucopyranoside (pNPG) as substrate and acetate buffer $(50 \mathrm{mM}, \mathrm{pH} 5.0)$. The enzymatic reaction was carried out at $50{ }^{\circ} \mathrm{C}$ for $30 \mathrm{~min}$ and p-nitrophenol liberated was measured at $405 \mathrm{~nm}$. One International unit (IU) of enzyme activity will be defined as the quantity of enzyme required to liberate $1 \mu \mathrm{mol}$ of 
glucose or p-nitrophenol per millilitre of crude filtrate per minute under standard assay conditions.

Laccase, tannase, lignin peroxidase and Mn peroxidase were determined by methods described in Salgado et al. (2014b).

\subsection{Statistical analysis}

Results are presented as the mean \pm standard deviation (SD) of at least two replicates. The analyses were carried out using Microsoft Office Excel software. Statistically significant differences of the several assays tested in Section 2.4 were evaluated by a one-way ANOVA. A significant difference was considered if $P<0.05$ applying the Tukey multiple-comparisons or Fisheŕs least significant difference (LSD). Statistical analyses were performed using Statgraphics plus 5.1 software.

The full factorial design $3^{2}$ allowed to estimate the significance of parameters and their interaction using Student's $t$-tests. The experimental design was performed in 11 experiments with three replicates in the center point. For statistical calculation, the variables were coded according to Eq. (1).

$x_{i}=\left(\chi_{1}-\chi_{0}\right) / \delta \chi$

wherein $x_{i}$ is the dimensionless coded value of the independent variable, $x_{0}$ is the value of independent variable at the centre point, and $\delta X$ is the step change. The interrelationship between dependent and independent variables was established in the Eq. (2).

$$
\begin{aligned}
Y= & b_{0}+b_{1} \cdot x_{1}+b_{11} \cdot x_{1}^{2}+b_{2} \cdot x_{2}+b_{22} \cdot x_{2}^{2}+b_{12} \cdot x_{1} \cdot x_{2} \\
& +b_{112} \cdot x_{1}^{2} \cdot x_{2}+b_{122} \cdot x_{1} \cdot x_{2}^{2}+b_{1122} \cdot x_{1}^{2} \cdot x_{2}^{2}
\end{aligned}
$$

wherein $Y$ is the dependent variable, $b$ are the regression coefficients (calculated from experimental data by multiple regression using the least-squares method) and $x$ are independent variables (coded). All experiments were carried out in duplicate and in randomized run order. The experimental data were evaluated by response surface methodology using Statistica 5.0 software. Dependent variables were optimized using an application of commercial software (Solver, Microsoft Excel 2007, Redmon, WA, USA).

\section{Results and discussion}

3.1. Screening of cellulases and xylanases producers by Congo red tests

The initial screening step consisted of observation of the growth of eleven strains of filamentous fungi on agar plates using carboxymethylcellulose (CMC) or xylan as carbon source. The EI can be used as a rapid and simple methodology to select strains that have potential for the production of enzymes. Table 1 shows the EI of the assays, the results were analysed by a multiple comparison test (Fisheŕs least significant difference) to determine the means that were significantly different from other means. The best producers of cellulases were A. niger CECT 2915, A. ibericus MUM 03.49 and $A$. uvarum MUM 08.01. Their EI were significantly different from the others fungi except to the A. carbonarius 01UAs130 and $A$. niger $01 \mathrm{UAs} 181$ which also achieved a higher value of EI. In xylanase assays, A. niger CECT 2915, A. ibericus MUM 03.49 and $A$. uvarum MUM 08.01 also were the fungi that achieved maximum value of EI, their EI values were significantly similar among themselves and significantly different to others fungi. Based on these preliminary data, A. niger CECT 2915, A. ibericus MUM 03.49 and $A$. uvarum MUM 08.01 were selected for further studies.

\subsection{Effect of residual oil extraction on physicochemical characteristics of olive pomace}

The solid wastes from olive mills were characterized to assess their potential as solid substrate in SSF and to evaluate the effect of residual oil extraction from olive pomace on the physicochemical characteristics. The crude olive pomace (COP) is obtained after two-phase extraction processes and the exhausted olive pomace (EOP) is obtained after drying and residual olive oil extraction by organic solvents. The drying and extraction of residual oil are physicochemical treatments that can change the composition of olive pomace (Roig et al., 2006). Usually, the crude olive pomace is centrifuged to extract the residual oil, followed by a drying process $\left(400-800{ }^{\circ} \mathrm{C}\right)$ that reduces moisture from $60-70 \%$ to $8 \%$ and extraction with solvents (hexane) (Rincón et al., 2012).

Table 2 shows the physical and chemical composition of COP and EOP (on a dried weight basis). A paired-sample comparison

Table 2

\begin{tabular}{|c|c|c|c|c|}
\hline Parameter & COP & EOP & $P$-value & Significant difference \\
\hline Humidity (\%) & $73.5 \pm 0.4$ & $9.9 \pm 0.1$ & 0.000004 & Yes \\
\hline Total solids (\%) & $26.5 \pm 0.4$ & $90.1 \pm 0.1$ & 0.000004 & Yes \\
\hline Ash (\%) & $6.6 \pm 0.5$ & $3.4 \pm 0.2$ & 0.004 & Yes \\
\hline Lignin (\%) & $43.2 \pm 0.5$ & $41.62 \pm 0.04$ & 0.074 & No \\
\hline Hemicellulose (\%) & $22.3 \pm 0.8$ & $24.1 \pm 0.2$ & 0.076 & No \\
\hline Cellulose (\%) & $12.5 \pm 0.9$ & $11 \pm 2$ & 0.250 & No \\
\hline Lipids (\%) & $16.65 \pm 0.09$ & $4 \pm 2$ & 0.036 & Yes \\
\hline Proteins (mg/g dry waste) & $4 \pm 1$ & $2.6 \pm 0.3$ & 0.143 & No \\
\hline Reducing Sugars (mg/gdry waste) & $96 \pm 6$ & $42 \pm 2$ & 0.002 & Yes \\
\hline Phenols ( $\mathrm{mg} / \mathrm{g}_{\text {dry }}$ waste $)$ & $8.4 \pm 0.3$ & $8.9 \pm 0.2$ & 0.006 & Yes \\
\hline $\mathrm{N}(\%)$ & $0.6 \pm 0.1$ & $1.27 \pm 0.07$ & 0.011 & Yes \\
\hline $\mathrm{C}(\%)$ & $49.7 \pm 0.7$ & $46 \pm 1$ & 0.116 & No \\
\hline $\mathrm{Ca}(\mathrm{g} / \mathrm{kg})$ & $1.16 \pm 0.04$ & $1.8 \pm 0.2$ & 0.053 & No \\
\hline $\mathrm{K}(\mathrm{g} / \mathrm{kg})$ & $17 \pm 1$ & $14.2 \pm 0.7$ & 0.136 & No \\
\hline $\mathrm{Mg}(\mathrm{mg} / \mathrm{kg})$ & $474 \pm 22$ & $473 \pm 57$ & 0.494 & No \\
\hline $\mathrm{Zn}(\mathrm{mg} / \mathrm{kg})$ & $12 \pm 0$ & $10.5 \pm 0.7$ & 0.102 & No \\
\hline $\mathrm{Cu}(\mathrm{mg} / \mathrm{kg})$ & $11.5 \pm 0.7$ & $11 \pm 1$ & 0.398 & No \\
\hline $\mathrm{Fe}(\mathrm{mg} / \mathrm{kg})$ & $42 \pm 2$ & $147 \pm 33$ & 0.074 & No \\
\hline $\mathrm{Mn}(\mathrm{mg} / \mathrm{kg})$ & $8.6 \pm 0.1$ & $10.2 \pm 0.4$ & 0.078 & No \\
\hline $\mathrm{Cr}(\mathrm{g} / \mathrm{kg})$ & $<22$ & $<22$ & & \\
\hline $\mathrm{Ni}(\mathrm{mg} / \mathrm{kg})$ & $<22$ & $<22$ & & \\
\hline $\mathrm{Pb}(\mathrm{mg} / \mathrm{kg})$ & $<22$ & $<22$ & & \\
\hline $\mathrm{Na}(\mathrm{mg} / \mathrm{kg})$ & $373 \pm 35$ & $92 \pm 5$ & 0.032 & Yes \\
\hline
\end{tabular}

Comparison of physicochemical composition of COP and EOP with a paired $t$-test at $95 \%$ confidence level. 
t-test was used to compare both wastes and to determine differences at 95\% confidence level. The null hypothesis was that the differences between the results of waste characterization before and after residual oil recovery were not significant. The moisture of COP $(73.5 \%)$ was significantly higher than EOP that showed low moisture (9.9\%) due to the drying stage after residual oil recovery. The content of cellulose, hemicellulose and lignin was significantly similar in both wastes. The extraction of residual oil by hexane did not affect the lignocellulosic composition of wastes. Although the organic solvents are used for fractionation of lignocellulosic materials to study the structure of lignin, the use of hexane was not reported in lignocellulose treatments. Other organic solvents are frequently used as ethanol, dioxane and acetone (Li et al., 2016). The content of cellulose and hemicellulose indicated that these wastes have potential to be used as solid substrate in SSF and can induce the production of lignocellulolytic enzymes.

The lipids concentration in EOP was significantly lower than in COP. The residual oil extraction recovered $75 \%$ of lipids from COP. The presence of lipids in solid substrate can induce the production of lipases, the production of lipases by A. ibericus using COP as solid substrate has already been studied by Oliveira et al. (2016). The concentration of free protein, sugars and phenols was determined after water extraction. Difference of protein concentration among substrates was not significant; however, the concentration of free sugars was significantly higher before residual oil extraction. Although free sugars as glucose can repress the microbial enzyme synthesis, in SSF the presence of free sugars on solid substrate favour the growth of fungi (Ertan-Inceoğlu et al., 2014). The concentration of total phenols was similar in both wastes. Olive pomace usually is rich in polyphenols, which could be used in pharmaceutical, cosmetic and food industries, and its recovery may be an alternative for revalorization of olive pomaces (Obied et al., 2005), moreover polyphenols presence can be harmful for SSF since it can inhibit fungal growth (Medina et al., 2011).

The analysis of the content of $\mathrm{N}$ and $\mathrm{C}$ showed a significant increase of $\mathrm{N}$ content and a not significant variation of $\mathrm{C}$ after extraction of residual oil. $\mathrm{C} / \mathrm{N}$ ratio of the COP and EOP, were, respectively, 83 and 36 . Carbon and nitrogen sources are important components for fungal growth and should be given significant consideration (Rodríguez-Leon et al., 2008). The optimum C/N ratio for SSF is closed to 15 (Lemos et al., 2001), so that to achieve this value additional source of $\mathrm{N}$ should be added.

As regards the olive pomaces mineral content, the values were not significantly different in both residues, except $\mathrm{Na}$ that was higher in COP. These residues were rich in $\mathrm{K}$, which is a common characteristic in OMW and by-products as reported by Alburquerque et al. (2004). The macro and micronutrients content in residues was similar to the other residues studied (Roig et al., 2006). The concentration of heavy metals in COP residues is almost non-existent. In analysis of the COP and EOP, heavy metals such as $\mathrm{Cr}, \mathrm{Ni}$ and $\mathrm{Pb}$ showed a concentration lower than $22 \mathrm{mg} / \mathrm{kg}$.

\subsection{Screening by SSF of COP and EOP}

Filamentous fungi selected in previously screening step were evaluated by cultivation under SSF during a period of 6 days using as solid substrate COP and EOP. Fig. 1a y b show the activities of cellulases and xylanases achieved, respectively. The SSF using COP as solid substrate showed a low cellulase and xylanases activities. When EOP was used, $A$. niger achieved maximum activity for cellulases ( $38 \mathrm{U} / \mathrm{g}$ of solid substrate) and for xylanases ( $28 \mathrm{U} / \mathrm{g}$ of solid substrate). The use of olive pomace as solid substrate for cellulase and xylanase production was barely studied. Only in a preview own studies were identified their production after SSF (Salgado et al., 2014b, 2015)
The results were analysed by one-way ANOVA followed by a multiple comparison test, Tukey's Multiple Comparison Test. The differences observed between the cellulases and xylanases activities for the three fungi on EOP and COP were statistically significant $(P$-value $<0.0001)$, but differences in xylanase activities were not significant between A. uvarum on EOP and A. ibericus on EOP. The SSF with EOP as a solid substrate enhanced the production of cellulases and xylanases by any of the three studied strains. The undetectable enzymatic activity after SSF with COP is probably caused by the presence of high initial concentration of fats with recognized antimicrobial properties which delayed the beginning of the fermentation and, on the other hand, to the high concentration of lignin, which needs specific enzymes and high temperatures to be degraded. Cayuela et al. (2010) also referred that in composting processes of olive pomace (TPOMW) long composting periods are needed for this kind of material and concentrations of fats and phenols can inhibit growth of fungi. In addition, the content of $\mathrm{N}$ in COP $(0.6 \%)$ was lower than in EOP $(1.27 \%)$. This difference causes an increase of $\mathrm{C} / \mathrm{N}$ ratio of $\mathrm{COP}(83)$ versus $\mathrm{C} / \mathrm{N}$ ratio of EOP (36) which it is closer to the optimum value for SSF.

Otherwise, the EOP was subjected to a second extraction with organic solvents for recovery of residual olive oil. This process may have functioned as a pretreatment of the waste and to improve the accessibility to substrate by fungi, reflecting on the increase of enzymes activities.

In Fig. 1c is represented free sugars in control and fermented solids. It was observed a reduction of the concentration of reducing sugars in all of the fermentations comparatively to the control. Fig. 1d shows the evolution of total phenols content after SSF. The phenol concentration has also reduced in all conditions comparatively with the control. Besides the phenolic compounds being toxic to microorganisms, the fungi have the capacity to degrade the phenol compounds present in wastes. It also shows that the phenols concentration has increased in both residues in comparison to the characterization of initial waste which showed $8.4 \pm 0.3 \mathrm{mg} / \mathrm{g}$ of dry waste in COP and $8.9 \pm 0.2 \mathrm{mg} / \mathrm{g}$ of dry waste EOP. In COP control there was $27.4 \pm 0.9 \mathrm{mg} / \mathrm{g}$ of dry waste and in EOP $21 \pm 1 \mathrm{mg} / \mathrm{g}$ of dry waste. The sterilization of solid substrate could have broken the lignin bounds. A wide range of phenolic compounds is generated due to the lignin break down varying widely between different raw materials (Alvira et al., 2010).

\subsection{Ultrasounds pretreatment of EOP}

\subsubsection{Optimization of sonication conditions}

EOP was selected to evaluate the effect of ultrasounds pretreatment (US) on cellulases and xylanases production by A. niger in SSF. The US is a physical treatment with a low environmental impact that can favor the accessibility of fungi to hemicellulose and cellulose fraction. A factorial complete experimental design $\left(3^{2}\right)$ was carried out to study the effect of time of sonication and liquid to solid ratio. Table 3 describes the corresponding experimental matrix and the results obtained. The two responses studied were cellulases and xylanases activities per mass of dry solid substrate $(\mathrm{U} / \mathrm{g})$. According to the results, the cellulases activity varied from 13.38 to $37.88 \mathrm{U} / \mathrm{g}$ and xylanases activity varied from 7.53 to $70.86 \mathrm{U} / \mathrm{g}$. The statistical analysis of the results yielded an empirical coded model for cellulases and xylanases activity as a function of the sonication time and L:S ratio. Table 4 lists the regression coefficients, their statistical significance (based on a $t$ test, with significance levels of $\alpha=0.05$ ) and the statistical parameters, such as, $F$ value, determination coefficient $\left(R^{2}\right)$ and significance level.

$R^{2}$ is the coefficient of determination and it is used to measure goodness of fit. The values of $R^{2}$ were found equal to 0.9972 for cellulases activity and 0.9997 for xylanases activity. The values of $R^{2}$ were close to 1 showing a good fitting of the model to the data 

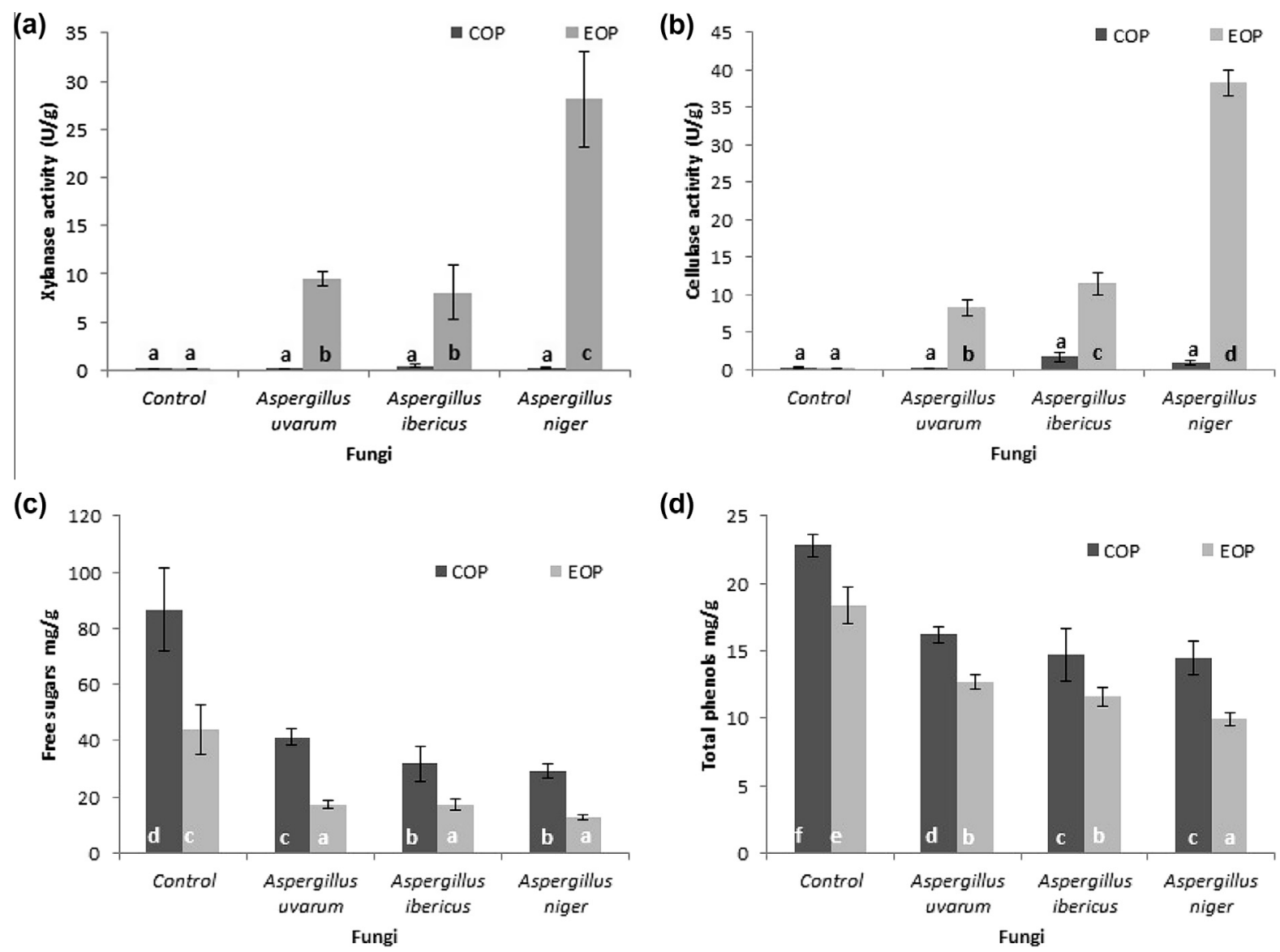

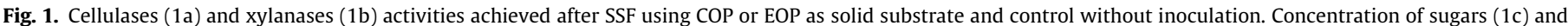

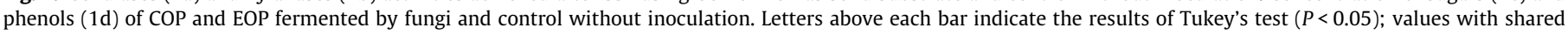
letters in the same graph are not significantly different.

Table 3

Response variables obtained according to the studied full factorial $3^{2}$ design to optimize US.

\begin{tabular}{|c|c|c|c|c|c|c|}
\hline \multirow[t]{4}{*}{ Runs } & \multirow{2}{*}{\multicolumn{2}{|c|}{ Independent variables }} & \multicolumn{4}{|c|}{ Dependent variable } \\
\hline & & & \multicolumn{2}{|c|}{ Cellulases production $\left(\gamma_{1}\right)$} & \multicolumn{2}{|c|}{ Xylanases production $\left(\gamma_{2}\right)$} \\
\hline & \multicolumn{2}{|l|}{ Real levels } & Observed & Predicted & Observed & Predicted \\
\hline & $\chi_{1}$ (Time, min) & $\chi_{2}(\mathrm{~L}: \mathrm{S}$ ratio) & $\gamma_{1}(\mathrm{U} / \mathrm{g})$ & $Y_{1}(\mathrm{U} / \mathrm{g})$ & $\gamma_{2}(\mathrm{U} / \mathrm{g})$ & $Y_{2}(\mathrm{U} / \mathrm{g})$ \\
\hline 1 & 5 & 3 & $37.88 \pm 4.47$ & 37.88 & $27.35 \pm 5.84$ & 27.35 \\
\hline 2 & 5 & 7 & $27.18 \pm 4.75$ & 27.18 & $28.84 \pm 2.34$ & 28.84 \\
\hline 3 & 5 & 11 & $13.38 \pm 3.33$ & 13.38 & $7.53 \pm 1.92$ & 7.53 \\
\hline 4 & 10 & 3 & $22.10 \pm 6.78$ & 22.10 & $11.46 \pm 1.06$ & 11.46 \\
\hline 5 & 10 & 7 & $15.80 \pm 3.88$ & 16.70 & $69.11 \pm 3.89$ & 70.05 \\
\hline 6 & 10 & 11 & $16.91 \pm 2.39$ & 16.91 & $26.88 \pm 3.27$ & 26.88 \\
\hline 7 & 15 & 3 & $27.34 \pm 5.71$ & 27.34 & $55.52 \pm 4.99$ & 55.52 \\
\hline 8 & 15 & 7 & $26.74 \pm 2.03$ & 26.74 & $69.86 \pm 3.17$ & 69.86 \\
\hline 9 & 15 & 11 & $23.02 \pm 7.91$ & 23.02 & $48.64 \pm 3.67$ & 48.64 \\
\hline 10 & 10 & 7 & $17.46 \pm 1.33$ & 16.70 & $70.86 \pm 8.83$ & 70.05 \\
\hline 11 & 10 & 7 & $16.85 \pm 0.66$ & 16.70 & $70.17 \pm 3.87$ & 70.05 \\
\hline
\end{tabular}

$\chi_{1}$ : time (uncoded); $\chi_{2}: \mathrm{L}: \mathrm{S}$ ratio.

$\gamma_{1}$ : cellulases activity; $\gamma_{2}$ : xylanases activity.

and indicating that $99 \%$ of the variability in the response could be explained by the model. The interaction of the independent variables and the optimum levels that have the most significant effect on dependent variable can be determined through the threedimensional response surface curve plot. Fig. 2a and b shows the effect of sonication time and L:S ratio on cellulases and xylanases production. As it can be observed in xylanases production, there is a clear optimum zone in the center of plot, thus intermediate time and $\mathrm{L}: \mathrm{S}$ ratio led to maximum xylanase production. On the other hand, the cellulase production was increases by increasing the time of US and decreasing the ratio L:S. The optimal conditions that led to maximum xylanases activity $(75.32 \mathrm{U} / \mathrm{g})$ were calculated with Solver tool showing $12.41 \mathrm{~min}$ and 7.27 of liquid and solid ratio as optimal parameters of US. To validate the model, an 
Table 4

Regression coefficients and correlation and statistical significance parameters of experimental design for cellulases and xylanases production.

\begin{tabular}{|c|c|c|c|c|c|}
\hline & Regression coefficients & Standard error & $t$ & $P$ & \\
\hline \multicolumn{6}{|c|}{ Cellulases production } \\
\hline$b_{0}$ & $16.70^{* * * *}$ & 0.4844 & 34.4761 & 0.0008 & \\
\hline$b_{1}$ & -0.22 & 0.5933 & -0.3742 & 0.7442 & \\
\hline$b_{11}$ & $10.26^{* * *}$ & 0.7659 & 13.3947 & 0.0055 & \\
\hline$b_{2}$ & $-2.60^{* *}$ & 0.5933 & -4.3765 & 0.0484 & \\
\hline$b_{22}$ & $2.80^{*}$ & 0.7659 & 3.6568 & 0.0673 & \\
\hline$b_{12}$ & $5.04^{* * *}$ & 0.4195 & 12.0223 & 0.0068 & \\
\hline$b_{112}$ & 0.00 & 0.7266 & -0.0055 & 0.9961 & \\
\hline$b_{122}$ & $-4.61^{* * *}$ & 0.7266 & -6.3383 & 0.0240 & \\
\hline$b_{1122}$ & $-4.3^{*}$ & 1.0558 & -4.1272 & 0.0540 & \\
\hline \multicolumn{6}{|c|}{ Xylanases production } \\
\hline$b_{0}$ & $70.05^{* * *}$ & 0.5102 & 137.2827 & 0.0001 & \\
\hline$b_{1}$ & $20.51^{* * * *}$ & 0.6249 & 32.8247 & 0.0009 & \\
\hline$b_{11}$ & $-20.69^{* * * *}$ & 0.8067 & -25.6515 & 0.0015 & \\
\hline$b_{2}$ & $7.71^{* * *}$ & 0.6249 & 12.3365 & 0.0065 & \\
\hline$b_{22}$ & $-50.87^{* * *}$ & 0.8067 & -63.0603 & 0.0003 & \\
\hline$b_{12}$ & $3.23^{* *}$ & 0.4419 & 7.3195 & 0.0182 & \\
\hline$b_{112}$ & $-3.19^{*}$ & 0.7653 & -4.1723 & 0.0529 & \\
\hline$b_{122}$ & $-14.38^{* * *}$ & 0.7653 & -18.7940 & 0.0028 & \\
\hline$b_{1122}$ & $36.28^{* * *}$ & 1.1120 & 32.6281 & 0.0009 & \\
\hline \multicolumn{6}{|c|}{ Correlation and statistical significance parameters } \\
\hline & $R$ & $R^{2}$ & $R^{2}$ adjusted & $F_{\exp }$ & $P$ \\
\hline$y_{1}$ & 0.9986 & 0.9972 & 0.9863 & 91.3837 & 0.0108 \\
\hline$y_{2}$ & 0.9998 & 0.9997 & 0.9987 & 967.7274 & 0.0010 \\
\hline
\end{tabular}

$P$ : probability; $R$ : multiple correlation coefficient; $R^{2}$ : determination coefficient. $\alpha=0.05 \%$.

$\gamma_{1}$ : cellulases activity; $\gamma_{2}$ : xylanases activity.

* Significant coefficient at $90 \%$.

** Significant coefficient at $95 \%$.

**** Significant coefficient at $99 \%$.

experiment was carried out in the optimal conditions. The confirmatory experiment showed similar activities between experimental $(71.21 \pm 8.37 \mathrm{U} / \mathrm{g})$ and predicted value $(75.32 \mathrm{U} / \mathrm{g})$.

To verify if the increased sonication time would affect the cellulases and xylanases production, two assays were carried out with the higher sonication times. The L:S ratio was fixed to the optimum conditions and the times were tested at $20 \mathrm{~min}$ and $30 \mathrm{~min}$. The results obtained showed that higher sonication times do not benefit the production of xylanases $(51.7 \pm 4.9$ at $20 \mathrm{~min} ; 33.23 \pm 1.97$ at $30 \mathrm{~min})$ and the difference on cellulases $(15.56 \pm 3.93$ at $20 \mathrm{~min} ; 18.84 \pm 4.86$ at $30 \mathrm{~min}$ ) production was not significant (based on a $t$ test, with significance levels of $\alpha=0.05$ ).

The effect of ultrasounds on lignocellulosic materials to be used on SSF was barely studied. Yang et al. (2012) observed a positive effect of US on xylanases production by Aspergillus japonicus using rice hull as solid substrate in SSF. This positive effect of ultrasounds pretreatment of lignocellulosic materials could improve the accessibility of fungi to hemicellulose fraction and to induce the xylanases production. In addition, the formation of microbubbles during sonication improves diffusivity or mass transfer processes increasing enzymes production (García et al., 2011). Yachmenev et al. (2009) showed that saccharification of cellulose is enhanced efficiently by US and that the maximum effects of cavitation occur at $50{ }^{\circ} \mathrm{C}$, which is the optimum temperature for many enzymes. The effect of ultrasounds on lignocellulosic biomass has been mainly employed for extracting hemicellulose, cellulose and lignin. The extractability of the wheat straw hemicelluloses was investigated using extraction method with application of ultrasonic irradiation in $0.5 \mathrm{M} \mathrm{KOH}$ aqueous solution. The results showed that ultrasonically assisted extraction in a period of 20-35 min produced a slightly higher yield of hemicelluloses and lignin (Sun and Tomkinson, 2002).

3.4.2. Comparison of US pretreatment with diluted acid pretreatment

The production of cellulases and xylanases was studied when the EOP was subjected to diluted acid hydrolysis ( $\mathrm{AH}$ ). It was also studied a combination of both pretreatments (US + AH). After SSF of pretreated solid by $\mathrm{AH}$, the cellulase and xylanase activities were $4.96 \pm 1.71$ and $35.05 \pm 3.65$. When US and AH were carried out, the cellulase and xylanase activities were $41.33 \pm 4.33$ and $3.6 \pm 0.6$, respectively. The data show that $\mathrm{AH}$ or US $+\mathrm{AH}$ did not enhance the enzyme activity. The US in the optimal conditions was the most effective pretreatment to produce cellulases and xylanases.

The dilute-acid at moderate temperatures effectively remove the hemicellulose fractions and the dissolved sugars (Knappert and Grethlein, 1981). In addition, little lignin is dissolved, because lignin is disrupted, in this way it is increased the cellulose susceptibility to enzymes (Yang and Wyman, 2004). In spite of this pretreatment has the advantage of solubilizing hemicellulose, mainly xylan to fermentable sugars, sugar degradation compounds are detected, and affect the microorganism metabolism in the fermentation step (Alvira et al., 2010). A variety of toxic compounds such as furfural and aromatic lignin degradation compounds, would be generated which may affect the growth of fungi.

Table 5 shows the variation of reducing sugars, proteins and phenols in liquid fraction and solid fraction (aqueous extract) after pretreatment and in the enzymatic extract and solid fraction (aqueous extract) after fermentation for the three pretreatments. The results show that most of the compounds remain in the liquid fraction after pretreatment.

After $\mathrm{AH}$, the concentration of sugars was $311 \pm 19 \mathrm{mg} / \mathrm{g}$ because the acid pretreatment solubilized monomeric sugars from hemicelluloses. In filtrate of the US + AH the sugars concentration was slightly lower. This waste was subjected to two pretreatments, US followed by $\mathrm{AH}$, and two filtrations. For proteins it is possible to observe an increase after the fermentation. The fermentation with the US treated waste presented the highest proteins concentration ( $3.7 \pm 0.5 \mathrm{mg} / \mathrm{g}$ solid subtract) and also achieved more enzymatic production. Analysing phenol compounds, the highest concentration was obtained in the liquid fraction after pretreatment due to the breaks in lignin. The filtrate may be a source of phenol compounds extracts. 
(a)
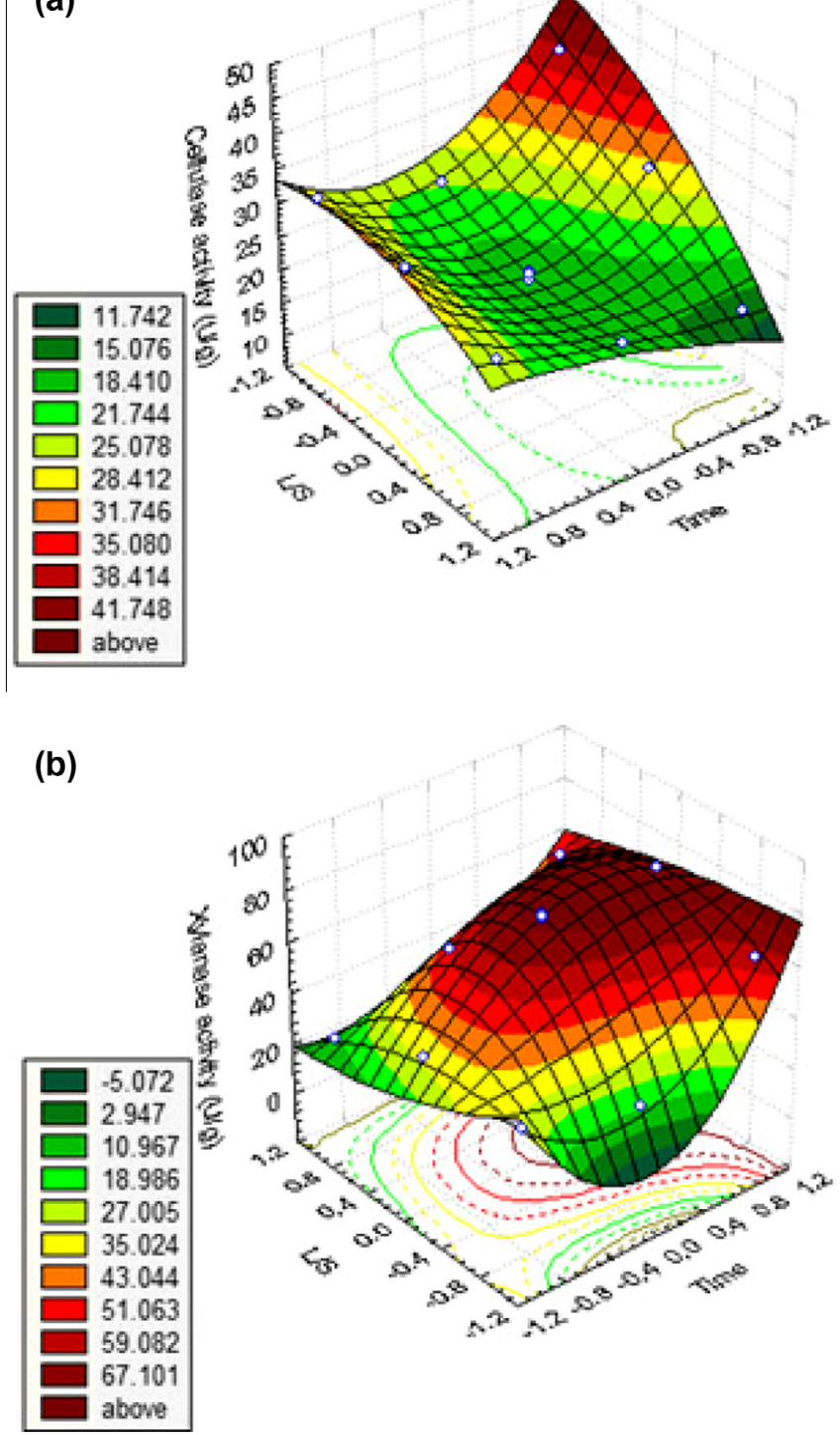

Fig. 2. Response surface for cellulases (2a) and xylanases (2b) production as a function of the time (coded) and L:S ratio (coded).

The effect of pretreatments in the removal of lignocellulosic compounds is shown in Table 6 and it was set the percentage of elimination for each compound after each treatment. When the
Table 6

Lignocellulose characterization of treated waste by $\mathrm{AH}, \mathrm{US}+\mathrm{AH}$ and US

\begin{tabular}{llll}
\hline Treatment & Lignin (\%) & Hemicellulose (\%) & Cellulose (\%) \\
\hline AH & $56.0 \pm 0.2$ & $7.9 \pm 0.6$ & $9.2 \pm 0.1$ \\
US + AH & $61 \pm 3$ & $9.7 \pm 0.3$ & $15.50 \pm 0.01$ \\
US & $38.5 \pm 0.7$ & $19 \pm 1$ & $9.4 \pm 0.7$ \\
Removed (\%) & & & \\
AH & 10 & 78 & 3 \\
US + AH & 14 & 76 & 18 \\
US & 24 & 30 & 25 \\
\hline
\end{tabular}

residue is treated with diluted acid, there is a high percentage of elimination of hemicellulose, $78 \%$ in $\mathrm{AH}$ and $76 \%$ in US + AH. However, the elimination of lignin and cellulose were much reduced. The removed percentage of the lignocellulosic material in US was reduced and practically the same for all the compounds.

\subsection{Study of enzymes production kinetics}

Cellulases and xylanases production during SSF was evaluated in the optimal conditions of US. In this study, the course of cellulases and xylanases activities during several days was evaluated and their values were represented in Fig. 3a. The highest xylanases activity ( $75 \pm 1 \mathrm{U} / \mathrm{g}$ solid substrate) was achieved after 7 days of fermentation, which is similar to the theoretical value predicted by the model of US. After this, the activity decreased, maybe due to proteolysis. Salgado et al. (2015) refer that low proteolytic activity can be an advantage when developing SSF processes, it may avoid inactivation of other secreted enzymes and benefit the accumulation of those in the substrate, improving production yields. The maximum cellulases activity ( $35 \pm 5 \mathrm{U} / \mathrm{g}$ solid subtract) was achieved after 11 days. Usually, short fermentation times are needed for xylanases production by SSF. Longer fermentation times favoured endocellulases production; this may be due to the need of a prior action of the xylanases to expose the cellulose fibres, which will induce cellulases production (Salgado et al., 2014b). Xu et al. (2008) achieved maximum activity at $48 \mathrm{~h}$. At the start and at each time of SSF, the $\mathrm{pH}$, reducing sugars, proteins and phenols concentration were analysed to follow the change of its composition waste (Fig. 3b). Sugars concentration decreased rapidly after 3 days of fermentation. Protein concentration increased relative to the start of fermentation during 11 days. Phenol concentration seemed to increase slightly. According to Giannoutsou et al. (2012) this slight increase may be the result of the degradation of polyphenols to smaller phenolic compounds that may be an indication that the microorganism could use the specific substrate for its growth. Salgado et al. (2015) also studied the course of the compounds over fermentation time and proved the depletion of the sugars, the increase of the proteins

Table 5

Characterization of liquid fraction and solid after pretreatment, enzymatic extract and solid after SSF.

\begin{tabular}{|c|c|c|c|c|}
\hline & Pretreatment & Reducing sugars ( $\left.\mathrm{mg} / \mathrm{g}_{\text {solid substrate }}\right)$ & Proteins $\left(\mathrm{mg} / \mathrm{g}_{\text {solid substrate }}\right)$ & Phenols ( $\left.\mathrm{mg} / \mathrm{g}_{\text {solid substrate }}\right)$ \\
\hline \multirow[t]{3}{*}{ Liquid fraction } & US & $311 \pm 19$ & $1.0 \pm 0.1$ & $27 \pm 1$ \\
\hline & $\mathrm{AH}$ & $287 \pm 0$ & $3.2 \pm 0.1$ & $17.2 \pm 0.6$ \\
\hline & $\mathrm{US}+\mathrm{AH}$ & $38.4 \pm 0.5$ & $1.5 \pm 0.2$ & $11.8 \pm 0.3$ \\
\hline \multirow[t]{3}{*}{ Enzymatic extract } & US & $3.0 \pm 0.5$ & $1.3 \pm 0.8$ & $2.8 \pm 0.5$ \\
\hline & $\mathrm{AH}$ & $2.8 \pm 0.3$ & $1.0 \pm 0.4$ & $2.9 \pm 0.1$ \\
\hline & $\mathrm{US}+\mathrm{AH}$ & $4.7 \pm 0.2$ & $3.7 \pm 0.5$ & $4.8 \pm 0.2$ \\
\hline \multirow[t]{3}{*}{ Pretreated solid ${ }^{*}$} & US & $2.53 \pm 0.03$ & n.d. & $1.33 \pm 0.02$ \\
\hline & $\mathrm{AH}$ & $2.42 \pm 0.01$ & n.d. & $1.23 \pm 0.01$ \\
\hline & $\mathrm{US}+\mathrm{AH}$ & $7.9 \pm 0.3$ & $0.59 \pm 0.03$ & $4.37 \pm 0.08$ \\
\hline \multirow[t]{3}{*}{ Pretreated and fermented solid ${ }^{*}$} & US & $1.4 \pm 0.1$ & n.d. & $1.38 \pm 0.07$ \\
\hline & $\mathrm{AH}$ & $1.2 \pm 0.3$ & n.d. & $1.5 \pm 0.2$ \\
\hline & $\mathrm{US}+\mathrm{AH}$ & $1.0 \pm 0.2$ & $0.018 \pm 0.004$ & $1.58 \pm 0.06$ \\
\hline
\end{tabular}

Liquid fraction: liquor obtained after pretreatment of solid and filtration.

Extraction with water 1:5 (w/v). 
(a)

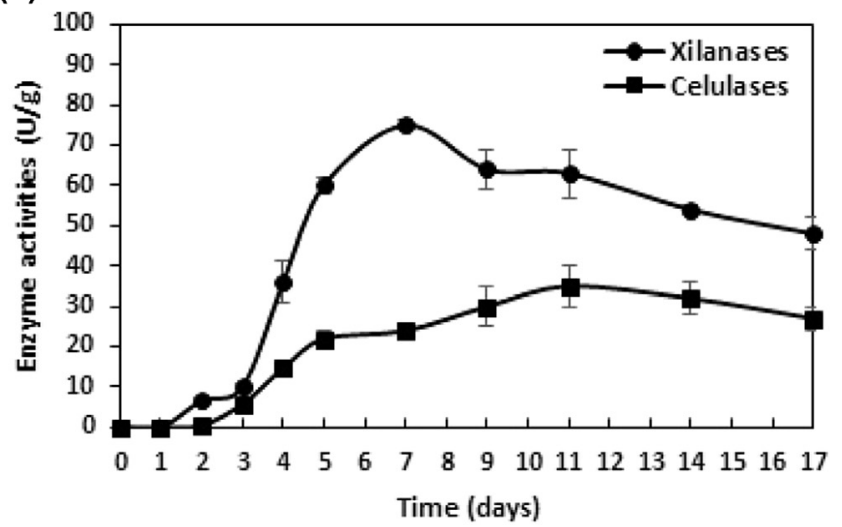

(b)

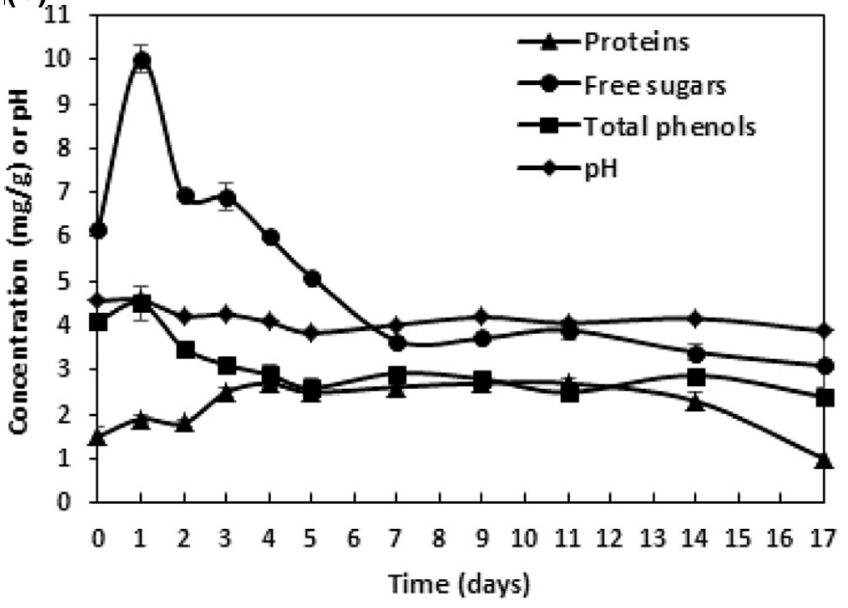

Fig. 3. Kinetics of cellulases and xylanases activities (3a), reducing sugars, proteins, phenols contents and $\mathrm{pH}(3 \mathrm{~b})$ of SSF using EOP treated by US in the optimal conditions.

percentage from $8.47 \%$ to $17.98 \%$ after 6 days of fermentation and the degradation of phenol compounds, obtaining $28.32 \%$ reduction of phenols after 10 days of fermentation.

The decrease in activity with increasing incubation time may be due to the production of by products resulting from microbial metabolism, as well as nutrient depletion, inhibiting fungal growth and enzyme formation (Shafique et al., 2009). The values of the $\mathrm{pH}$ vary between 3.84 and 4.57 . The optimal $\mathrm{pH}$ of the xylanases and cellulases production has been studied by several authors. Kumar et al. (2008) studied the effect of $\mathrm{pH}$ on cellulases production by A. niger, and it was observed that $\mathrm{pH} 5.5$ was optimal for maximum cellulases production.

\subsection{Effect of nutrients supplementation}

It was tested the production of lignocellulosic enzymes in SSF with different nutrient supplements to improve enzymes production. The enzyme activities achieved without supplementation of US pretreated EOP, supplemented with low cost nutrients solution ( $0.04 \mathrm{~g}$ urea/g substrate and $0.5 \mathrm{~mL}$ vinasses/g substrate) and addition of liquid fraction from US pretreatment. The SSF without nutrient supplementation barely produced lignocellulolytic enzymes, the cellulase activity was $1.13 \pm 0.38 \mathrm{U} / \mathrm{g}$ and the xylanase activity was $0.21 \pm 0.12 \mathrm{U} / \mathrm{g}$. The enzyme activities achieved by SSF with low cost nutrients (cellulase activity: $9.99 \pm 1.39 \mathrm{U} / \mathrm{g}$; xylanase activity: $19.44 \pm 3.85 \mathrm{U} / \mathrm{g}$ ) were lower than the activities achieved using commercial nutrients. Salgado et al. (2015) observed a positive effect of urea and vinasses as nutrient supplement in SSF carried out with mixtures of olive pomace, exhausted grape marc and vine trimming shoots.

The effect of the liquid fraction addition was also tested. The enzymatic activities achieved were $46 \pm 3$ and $100 \pm 15 \mathrm{U} / \mathrm{g}$ for cellulases and xylanases, respectively. The addition of liquid fraction to solid substrate increased the xylanase activity from 71 to $100 \mathrm{U} / \mathrm{g}$ and cellulase activity from 21 to $46 \mathrm{U} / \mathrm{g}$. Comparing to initial solid substrate without US pretreatment the increase of cellulase activity was $40.8 \%$ and the increase of xylanase activity was $119 \%$. Thus, the free sugars present in liquid fraction induce the production of lignocellulolytic enzymes and the compounds that are released to the filtrate after ultrasounds pretreatment favour the SSF. The growth of fungi can be favoured by the increase of soluble sugar at start of SSF. Various soluble sugars like glucose, xylose, arabinose, galactose help the initiation of growth and replication of microorganisms (Giannoutsou et al., 2012). Other enzymatic activities as $\beta$-glucosidases, laccases, tannases, lignin peroxidases and Mn-peroxidases were determined in the extract which did not show laccase and $\mathrm{Mn}$ - peroxidase activity. The extract presented $\beta$-glucosidase $(28.10 \pm 3.44 \mathrm{U} / \mathrm{g})$. In addition, it showed low lignin peroxidase $(0.65 \pm 0.02 \mathrm{U} / \mathrm{g})$ and tannase activity $(0.5 \pm 0.04 \mathrm{U} / \mathrm{g})$.

\section{Conclusions}

The COP showed a higher concentration of sugars and lipids than EOP. A. ibericus, A. niger, and A. uvarum were selected as the most efficient cellulases and xylanases producers. In addition, the production of cellulases and xylanases was higher in EOP compared to COP. US of EOP improved xylanase production by SSF. However it showed a negative effect on cellulase production. The production of xylanases requires shorts periods and production of cellulases needs longer periods. Finally, the addition of liquid fraction from US to solid pretreated improved the xylanase and cellulase production by SSF compared to untreated solid.

\section{Acknowledgements}

This study was supported by the Portuguese Foundation for Science and Technology (FCT) under the scope of the strategic funding of UID/BIO/04469/2013 unit and COMPETE 2020 (POCI01-0145-FEDER-006684). This study was supported by the Portuguese Foundation for Science and Technology (FCT) under the scope of the Project RECI/BBB-EBI/0179/2012 (FCOMP-01-0124FEDER-027462). José Manuel Salgado was supported by the grant SFRH/BPD/84440/2012 from Fundação para a Ciência e Tecnologia - FCT, Portugal.

\section{References}

Alburquerque, J.A., González, J., García, D., Cegarra, J., 2004. Agrochemical characterisation of "alperujo", a solid by-product of the two-phase centrifugation method for olive oil extraction. Bioresour. Technol. 91, 195-200.

Alvira, P., Tomás-Pejó, E., Ballesteros, M., Negro, M.J., 2010. Pretreatment technologies for an efficient bioethanol production process based on enzymatic hydrolysis: a review. Bioresour. Technol. 101, 4851-4861.

Azbar, N., Bayram, A., Filibeli, A., Muezzinoglu, A., Sengul, F., Ozer, A., 2004. A review of waste management options in olive oil production. Crit. Rev. Environ. Sci. Tecnol. 34, 209-247.

Cayuela, M.L., Sánchez-Monedero, M.A., Roig, A., 2010. Two-phase olive mill waste composting: enhancement of the composting rate and compost quality by grape stalks addition. Biodegradation 21, 465-473.

Ertan-Inceoğlu, F., Balkan, B., Yarkin, Z., 2014. Determination of the effects of initial glucose on the production of $\alpha$-amylase from Penicillium sp. under solid-state and submerged fermentation. Biotechnol. Biotechnol. Equip. 28, 96-101.

García, A., Alriols, M.G., Llano-Ponte, R. Labidi, J, 2011. Ultrasound-assisted fractionation of the lignocellulosic material. Bioresour. Technol. 102, 63266330. 
Gianico, A., Braguglia, C.M., Mescia, D., Mininni, G., 2013. Ultrasonic and thermal pretreatments to enhance the anaerobic bioconversion of olive husks. Bioresour. Technol. 147, 623-626.

Giannoutsou, E.P., Katsifas, E., Geli, A., Karagounia, D., 2012. Protein increase and lysine production by a Paecilomyces variotii strain grown on two-phase olive mill waste. World J. Microbiol. Biotechnol. 28, 849-856.

Holtzapple, M.T., Humphrey, A.E., 1984. The effect of organosolv pretreatment on the enzymatic hydrolysis of poplar. Biotechnol. Bioeng. 26, 670-676.

Khdair, A.I., Ayoub, S., Abu-Rumman, G., 2015. Effect of pressing techniques on olive oil quality. Am. J. Food Technol. 10, 176-183.

Knappert, D., Grethlein, H., 1981. Converse A. Partial acid hydrolysis of poplar wood as a pretreatment for enzymatic hydrolysis. Biotechnol. Bioeng. Symp., 11-77

Kumar, R., Singh, S., Singh, O.V., 2008. Bioconversion of lignocellulosic biomass: biochemical and molecular perspectives. J. Ind. Microbiol. Biotechnol. 35, 377391.

Li, M., Yang, S., Sun, R., 2016. Recent advances in alcohol and organic acid fractionation of lignocellulosic biomass. Bioresour. Technol. 200, 971-980.

Lemos, J.L.S., De A Fontes, M.C., Pereira Jr., N., 2001. Xylanase production by aspergillus awamori in solid-state fermentation and influence of different nitrogen sources. Appl. Biochem. Biotechnol. Part A 91-93, 681-689.

Medina, E., Romero, C., de Los Santos, B., de Castro, A., García, A., Romero, F., Brenes, M., 2011. Antimicrobial activity of olive solutions from stored Alpeorujo against plant pathogenic microorganisms. J. Agric. Food Chem. 59, 6927-6932.

Morillo, J.A., Antizar-Ladislao, B., Monteoliva-Sánchez, M., Ramos-Cormenzana, A., Russell, N.J., 2009. Bioremediation and biovalorisation of olive-mill wastes. Appl. Microbiol. Biotechnol. 82, 25-39.

Niaounakis, M., Halvadakis, C.P., 2006. Thermal Processes in Olive Processing Waste Management: Literature Review and Patent Survey. Elsevier, Amsterdan, pp. $123-135$.

Obied, H.K., Allen, M.S., Bedgood, D.R., Prenzler, P.D., Robards, K., Stockmann, R., 2005. Bioactivity and analysis of biophenols recovered from olive mill waste. J. Agric. Food Chem. 53, 823-837.

Oliveira, F., Moreira, C., Salgado, J.M., Abrunhosa, L., Venâncio, A., Belo, I., 2016. Olive pomace valorization by aspergillus species: lipase production using solid-state fermentation. J. Sci. Food Agric. http://dx.doi.org/10.1002/jsfa.7544.

Pandey, A., Soccol, C.R., Larroche, C., 2007. Current Developments in Solid-state Fermentation. Springer Science/Asiatech Publishers, Inc., New York, USA/New Delhi, India, pp. 3-25.

Rincón, B., Fernando, G., Fermoso, F.G., Borja, R., 2012. Olive oil mill waste treatment: improving the sustainability of the olive oil industry with anaerobic digestion technology. In: Boskou, D. (Ed.), Olive Oil - Constituents, Quality, Health Properties and Bioconversions. Publisher In Tech, Rijeca, pp. 275-292.
Rincón, B., Bujalance, L., Fermoso, F.G., Martín, A., Borja, R., 2014. Effect of ultrasonic pretreatment on biomethane potential of two-phase olive mill solid waste: kinetic approach and process performance. Sci. World J., 9 Article ID 648624.

Rodríguez-Leon, J., Soccol, C., Pandey, A., Rodríguez, D., 2008. Factors affecting solistate fermentation. Current Developments in Solid-State Fermentation. Springer, New York, pp. 26-47.

Roig, A., Cayuela, M.L., Sánchez-Monedero, M.A., 2006. An overview on olive mil wastes and their valorisation methods. Waste Manage. 26, 960-969.

Salgado, J.M., Abrunhosa, L., Venâncio, A., Domínguez, J.M., Belo, I., 2014a. Integrated use of residues from olive mill and winery for lipase production by solid state fermentation with Aspergillus sp. Appl. Biochem. Biotechnol. 172 $1832-1845$.

Salgado, J.M., Abrunhosa, L., Venâncio, A., Domínguez, J.M., Belo, I., 2014b. Screening of winery and olive mill wastes for lignocellulolytic enzyme production from Aspergillus species by solid-state fermentation. Biomass Convers. Biorefin. 4, 201-209.

Salgado, J.M., Abrunhosa, L., Venâncio, A., Domínguez, J.M., Belo, I., 2015. Enhancing the bioconversion of winery and olive mill waste mixtures into lignocellulolytic enzymes and animal feed by Aspergillus uvarum using a packed-bed bioreactor. J. Agric. Food Chem. 63, 9306-9314.

Shafique, S., Bajwa, R., Shafique, S., 2009. Screening of Aspergillus niger and A. Flavus strains for extra cellular alpha-amylase activity. Pak. J. Bot. 41, 897-905.

Sun, R.C., Tomkinson, J., 2002. Characterization of hemicelluloses obtained by classical and ultrasonically assisted extractions from wheat straw. Carbohydr. Polym. 50, 263-271.

Taherzadeh, M.J., Karimi, K., 2008. Pretreatment of lignocellulosic wastes to improve ethanol and biogas production: a review. Int. J. Mol. Sci. 9 (9), 1621-1651.

Xu, Y., Li, Y., Xu, S., Liu, Y., Wang, X., Tang, J., 2008. Improvement of xylanase production by Aspergillus niger XY-1 using response surface methodology for optimizing the medium composition. J. Zhejiang Univ. Sci. B 9, 558-566.

Yachmenev, V., Condon, B., Klasson, T., Lambert, A., 2009. Acceleration of the enzymatic hydrolysis of corn stover and sugar cane bagasse celluloses by low intensity uniform ultrasound. J. Biobased Mater. Bioenergy 3, 25-31.

Yang, B., Wyman, C.E., 2004. Effect of xylan and lignin removal by batch and flowthrough pretreatment on the enzymatic digestibility of corn stover cellulose. Biotechnol. Bioeng. 86, 88-98.

Yang, C.Y., Sheih, I.C., Fang, T.J., 2012. Fermentation of rice hull by Aspergillus japonicus under ultrasonic pretreatment. Ultrason. Sonochem. 19, 687-691.

Zimbardi, A.L.R.L., Sehn, C., Meleiro, L.P., Souza, F.H.M., Masui, D.C., Nozawa, M.S.F., Furriel, R.P.M., 2013. Optimization of $\beta$-glucosidase, $\beta$-xylosidase and xylanase production by colletotrichum graminicola under solid-state fermentation and application in raw sugarcane trash saccharification. Int. J. Mol. Sci. 14, 2875-2902. 